\title{
Potential of Chitinolytic Bacteria Derived from Anadara granosa Shell to Inhibit Fusarium sp and Rhizoctonia solani Growth
}

\author{
Nur Haedar*, As’adi Abdullah and Besse Fitriani \\ Department of Biology, Faculty of Mathematics and Natural Sciences, \\ Hasanuddin University, Makassar-90245, Indonesia \\ *Corresponding author:
}

\begin{tabular}{|c|c|}
\hline & A B S T R A C T \\
\hline $\begin{array}{l}\text { Ke y w or d s } \\
\text { Chitinolytic } \\
\text { bacteria, } \\
\text { Anadara granosa } \\
\text { shell, Inhibition. }\end{array}$ & $\begin{array}{l}\text { This study aimed to get chitinolytic bacteria derived from shell Anadara granosa } \\
\text { which has ability to inhibit growth of pathogenic fungi Fusarium sp. and Rhizoctonia } \\
\text { solani. Shell samples taken from Paoterearea then isolated on an agar medium chitin, } \\
\text { colonies that grow and establish a clear zone chitinolytic bacterial isolates. } \\
\text { Chitinolytic bacteria grow and form a clear zone. Result of bacterial isolation obtained } \\
\text { eight of chitinolytic bacteria i.e., IK-A, IK-B, IK-C, IK-D, IK-E, IK-F, IK-G, IK-H. }\end{array}$ \\
\hline Article Info & $\begin{array}{l}\text { Based on test inhibitory effect on pathogenic fungi Rhizoctonia solani, IK-A bacterial } \\
\text { isolates showed the greatest inhibition by } 1.21 \mathrm{~cm} \text { while the smallest inhibitory i.e., }\end{array}$ \\
\hline $\begin{array}{l}\text { Accepted: } \\
15 \text { March } 2017 \\
\text { Available Online: } \\
12 \text { April } 2017\end{array}$ & $\begin{array}{l}\text { IK-H with } 0.70 \mathrm{~cm} \text { at } 1 \times 24 \text { hours incubation. While the fungal pathogen Fusarium sp. } \\
\text { of eight isolates of bacteria, none of which showed positive results. Then made } \\
\text { macroscopic observations by looking at colony (shape, elevation and ledges), } \\
\text { microscopic (gram staining) and biochemical test (Motility, MR, VP, TSIA). }\end{array}$ \\
\hline
\end{tabular}

\section{Introduction}

Anadara granosa is one type of shellfish waters which mostly found areas along northern coast of Java island, east coast of Sumatra, Lombok, Bima bay, Buton Strait and Sulawesi. Anadara granosa often referred as blood shell because brownish-red color on its flesh. Utilization of blood shell generally only meat alone while shell is discarded. Based on high level of consumption of shells caused number of waste generated shell which has not been optimal utilization (Irwani et al., 2012). Flesh of shell with content of 9$13 \%$ protein, $0-2 \%$ fat, glycogen $1-7 \%$ thus serves as a source of food (Waterman in Budiyanto et al., 1990). Besides flesh, shells also contain chitin. Chitin contained in shells are in the range of $14-35 \%$ depending on species (John et al., 2013).

Chitin is used as an ingredient in cosmetics, pharmaceutical materials, biochemical and pet food. Existence of abundant chitin and rapidly degraded by bacteria and fungi that have enzymes that can degrade chitin. Bacteria that can degrade chitin called chitinolytic bacteria.

Chitinolytic bacteria interest to be isolated because of its ability to hydrolyze chitin by chitinase enzyme (Suryanto et al., 2005). Microorganisms are source of enzyme most widely used compared to plants and animals. As a source of enzymes, microorganisms 
more profitable because of rapid growth, can grow on a substrate that is cheaper and easier improved result by setting growth conditions. Enzymes are catalysts that can reduce pollution impact and waste of energy because reaction does not require high energy, specific and non-toxic (Aunstrup et al., 1979).

Chitinolytic bacteria are potentially used as a biological control against pathogenic fungi and pests, because both of these microorganisms have chitin components in their cell wall. Chitinolytic bacteria able to secrete an enzyme that can break down cell walls of fungi and pests that have chitin component. Chitin-degrading enzyme is chitinase produced by some biological control agents such as fungi and bacteria form extracellular enzymes (Pal and Gardene, 2006). Microorganism is a biological control that is widely used because it is safe for surrounding ecosystem and environment friendly. Enzymes produced by microorganisms can degrade cell wall of pathogenic fungus that can suppress growth and development of these organisms, which in turn can reduce level of their attacks.

\section{Materials and Methods}

Materials used in this study were sampled shells of Anadara granosa as a source of bacterial isolates chitinolytic and isolates of Fusarium sp and Rhizoctonia solani.

\section{Isolation of chitinolytic bacteria}

Shell of outside and inside of shells Anadara granosa taken using Swab method that is by greasing the surface of shells Anadara granosa outside and inside as much as 2-3 times. Furthermore, dissolved in physiological saline then diluted to $0.99 \%$ dilution $10^{-6}$, three final dilution is stored on chitin media and incubated in an incubator for 48 hours at temperature of $37^{\circ} \mathrm{C}$.Colonies that grow and form a clear zone around colony is chitinolytic bacterial isolates, further isolates obtained replanted on same medium to obtain pure isolates.

\section{Rejuvenation of pathogenic fungi Rhizoctonia solani and Fusarium spIsolates}

Pathogenic fungi Rhizoctonia solani and Fusarium sp rejuvenated by taking each one OSE isolates and grown using scratches methods on PDA medium with quadrant method on a Petri dish.

Test of antagonist chitinolytic bacteria against pathogens Rhizoctonia solani and Fusarium sp

\section{Preparation of suspension chitinolytic} bacteria

Two-three dose bacterial culture that has rejuvenated by detaching from slanted media and entered into Erlenmeyer flask containing $30 \mathrm{ml}$ of chitin media, shacked until homogeneous and came up with the bacterial suspension.

\section{Preparation of suspension Rhizoctonia solani and Fusarium sp}

As many as one ose each fungal isolates that have been rejuvenated added at $7 \mathrm{ml}$ sterile distilled water and then homogenized. Furthermore, measured value of transmittance is $75 \%$ in spectrophotometer with $1 \mathrm{~mL}$ isolates enter into cuvettes then measured with wavelength of $580 \mathrm{~nm}$.

Test inhibitory effect of chitinolytic bacteria on Rhizoctonia solani and Fusarium sp growth

Tests conducted by diffusion method using paper disks with diameter of $0.6 \mathrm{~mm}$. PDA medium added fungal pathogens therein 
shaken until homogeneous and poured in a Petri dish and allowed to solidify. Then paper disk that has been soaked in bacterial suspension for 10 minutes laid on surface of PDA medium with symmetrical position in Petri dish, then incubated at $37^{0} \mathrm{C}$ for $1-2 \times 24$ hours.

\section{Characterization of chitinolytic bacteria (Muharni et al., 2011)}

Characterization of chitinolytic bacteria includes observation of macroscopic, microscopic (gram staining), motility and biochemical tests (MR-VP and TSIA).

\section{Results and Discussion}

\section{Isolation of chitinolytic bacteria}

Chitinolytic bacteria isolated from Anadara granosa taken from Paotere, Makassar where the fish auction takes place. Isolation of chitinolytic bacteria carried from Anadara granosa inside and outside with Swab method then dilution terraced up $10^{-6}$ (Fig. 1) Four final dilution was poured on chitin medium and incubated for $3 \times 24$ hours with temperature of $37^{\circ} \mathrm{C}$. Colonies that grow and form clear zone is chitinolytic bacterial isolates. According Pleban (1987) clear zone formed around colonies of bacteria indicates chitinolytic activity in growth media. According Joklik and Smith (1968) a clear zone formed by the enzyme chitinolytic issued by the bacterial cell to break down chitin macromolecules into smaller molecules of chitin. Chitinolytic enzymes secreted by bacteria in medium bound particles of chitin (colloidal chitin) thus become degraded chitin and chitin composition in medium to be reduced. From results of isolation obtained eight isolates (CI A, CI B, CI C, D IK, IK E, F IK, G IK, IK H). The eight isolates was observed growth of colony and purified several times using quadrant streak technique in order to obtain bacterial colonies that really pure.
Rejuvenation of pathogenic fungi Rhizoctonia solani and Fusarium sp isolates

Isolates of fungal pathogens Rhizoctonia solani used from collection of Microbiology Laboratory, Department of Biology, State Islamic University, Makassar. Isolates of Fusarium sp derived from Centre of Research Agriculture Biotechnology, Hasanuddin University, Makassar. Rhizoctonia solani culture rejuvenated on Potato Dextrose Agar (PDA) medium and incubated at $37^{\circ} \mathrm{C}$ for $3-4$ $\mathrm{x} 24$ hours with isolate characteristics of early white and then turns green at the top. For Fusarium sp rejuvenated on Potato Dextrose Agar (PDA) medium and incubated for 5-6 x 24 hours with characteristic mycelium initially white and darker becomes creamy. Results of rejuvenation fungal isolates can be seen in the following figure 2 .

Test of antagonist chitinolytic bacteria against pathogens Rhizoctonia solani and Fusarium sp

Result of inhibition test, eight chitinolytic bacteria isolates i.e., IK-A, IK-B, IK-C, IK-D, IK-E, IK-F, IK IK-G and $\mathrm{H}$ against fungus Fusarium sp and Rhizoctonia solani were incubated for 1-2 x 24 hours showed different results for each fungus, can be seen in figures 3 and 4.

Inhibition test results of eight isolates chitinolytic bacteria against Rhizoctonia solani and Fusarium sp growth shows inhibition zone values are different can be seen from table 1 .

Based on the above table it can be seen that inhibition test against Rhizoctonia solani on first day, A isolates have the greatest inhibition zone is $1.21 \mathrm{~cm}$ whereas the smallest inhibitory zone shown by $\mathrm{H}$ isolates is $0.70 \mathrm{~cm}$. Inhibition zone seen only on the first day because on the second day inhibition 
zone was covered by fungal hyphae. Therefore it can be concluded that origin of chitinolytic bacteria from Anadara granosa shells are fungi statik which can inhibit growth of pathogenic fungi without shutting. Results of inhibition test between chitinolytic bacteria against $R$. solani showed that ability to inhibit growth of fungus Rhizoctonia solani is varied, characterized by differences in the size of inhibition zone is formed. Chitinolytic bacteria are bacteria capable of degrading chitin compound with chitinase enzyme. Chitinase enzyme produced can hydrolyze $\beta$ 1,4 bond between $\mathrm{N}$-acetylglucosamine (NAcGlc) subunit on chitin polymer which is constituent of cell wall fungus $R$. solani (Khaeruni et al., 2012). Gohel et al., (2006) stated that chitinolytic bacteria have some way to suppress the growth of pathogenic fungi, one of which bacteria utilize fungal hyphae as substrate for growth, through lysis of hyphae causing fungal cell walls become disrupted.

Based on these results it is known that bacterial origin chitinolytic Anadara granosa shells have potential to inhibit growth of pathogenic fungi Rhizoctonia solani so that it can be used as biocontrol agent. This is consistent with previous studies conducted by Khaeruni and Abdul (2012) chitinolytic bacteria capable of being biocontrol agent against Rhizoctonia solani causes rot in plants by applying to soybean plants are significant effect on plant height, leaf number and growth. Results of chitinolytic bacterial inhibition against Fusarium $s p$ show that chitinolytic bacteria from first day to second day, bacteria are not able to inhibit fungal growth is evident with inhibitory zone is not formed. This proves that not all species of fungi can be inhibited by chitinolytic bacteria. Schoffelmeer et al., (1999), states that composition of fungus $F$. oxysporum cell wall in outer layer there is glycoproteins are compounds that protect surface of mycelium, while chitin and glucan present in the inner layer. The content of glycoprotein on cell wall as much as $50-60 \%$ of cell wall total mass, where results of sugar analysis contained in cell wall $F$. oxysporum show that this fungus not only contains glucose and (N-acetyl) glucosamine but also mannose, galactose and uronik acid allegedly derived from glycoprotein of cell wall.

According Yurnaliza et al., (2011) state some proteins and lipids that coat of cell wall blocking chitinase enzyme activity and Fusarium sp compared fungal pathogens are more resistant to lysis.

\section{Characterization of chitinolytic bacteria}

Bacteria that have grown in a Petri dish observed morphologic to see colonies like shape, elevation, and the edges of the colony.

After observation of morphological characters, results obtained that $\mathrm{A}$ isolates have similar morphology to isolate $\mathrm{B}, \mathrm{C}, \mathrm{E}, \mathrm{F}$ and $\mathrm{G}$ (circular shape, flat surfaces, entire and colored white). $\mathrm{D}$ and $\mathrm{H}$ isolates have morphology (shape circular, flat surface, entire and colored cream). In addition to morphological observation, microscopic observation has also been conducted in form of gram staining to see structure of bacterial cell wall. The results showed that eight of chitinolytic bacterial isolates obtained is gram-negative, it is appropriate with the opinion of Kathiresan and Bingham (2001), which states that almost all marine bacteria are gram-negative. Obtainment of all isolates of gram-negative allegedly due to gramnegative bacteria have a cell wall structure is more complex than gram-positive bacteria. So the gram-negative bacteria are conditioned to survive extreme environments (Table 2).

Biochemical test aims to determine interaction of metabolites produced by bacteria with chemical reagents as well as the ability of bacterium using certain compounds 
as carbon and energy sources that can be used for identification. Results of biochemical tests of chitinolytic bacteria can be seen in table 3 . Results obtained from motility test that isolates IK-A, IK-B, IK-C, IK-D, IK-E, IK-F, $G$ and IK IK-H shows positive results characterized by spread of white like roots around the inoculation it shows the movement of bacteria inoculated, furthermore formation of $\mathrm{H}_{2} \mathrm{~S}$ marked with SIM media blackish color of the previously yellow. Based on the test results of TSIA chitinolytic bacteria obtained IK A, IK D, E and IK IK G yellow slant section and yellow butt section. IK B, IK C and $\mathrm{IKH}$ red slant section and yellow butt section, while IK F red slant section and red butt section.

Table.1 Value of inhibition zone from chitinolytic bacteria against Rhizoctonia solani and Fusarium sp growth

\begin{tabular}{cccccc}
\hline \multirow{2}{*}{ No. } & Isolates & \multicolumn{5}{c}{ Inhibition zone (cm) } \\
\cline { 3 - 6 } & Name & \multicolumn{2}{c}{ R. solani } & \multicolumn{2}{c}{ Fusariumsp } \\
& & $\mathbf{1 x 2 4}$ & $\mathbf{2 x 2 4}$ & $\mathbf{1 x 2 4}$ & $\mathbf{2 x 2 4}$ \\
\hline 1 & IK A & 1,21 & - & - & - \\
2 & IK B & 1,19 & - & - & - \\
3 & IK C & 1,19 & - & - & - \\
4 & IK D & 1,10 & - & - & - \\
5 & IK E & 0,76 & - & - & - \\
6 & IK F & 0,90 & - & - & - \\
7 & IK G & 1,10 & - & - & - \\
8 & IK H & 0,70 & - & - & - \\
\hline
\end{tabular}

Table.2 Observation results of chitinolytic bacterial morphology

\begin{tabular}{llllll}
\hline \multirow{2}{*}{ Isolates } & \multicolumn{4}{c}{ Morphological Observation } & \multirow{2}{*}{ Gram Staining } \\
\cline { 2 - 5 } & Form & Elevation & Margin & Color & \\
\hline IK A & Circular & Flat & Entire & White & Coccus (-) \\
IK B & Circular & Flat & Entire & White & Coccus (-) \\
IK C & Circular & Flat & Entire & White & Basil pendek (-) \\
IK D & Circular & Flat & Entire & Cream & Coccus (-) \\
IK E & Circular & Flat & Entire & White & Basil pendek (-) \\
IK F & Circular & Flat & Entire & White & Coccus (-) \\
IK G & Circular & Flat & Entire & White & Coccus (-) \\
IK H & Circular & Flat & Entire & Cream & Coccus (-) \\
\hline
\end{tabular}

Table.3 Biochemical test results of chitinolytic bacteria

\begin{tabular}{lcccllll}
\hline Isolates & \multirow{2}{*}{ Notilitas } & \multirow{2}{*}{ MR } & \multirow{2}{*}{ VP } & \multicolumn{5}{c}{ TSIA (SB) } \\
\cline { 5 - 8 } & & & & Slant & Butt & H2S & Gas \\
\hline IK A & + & + & - & Kuning & Kuning & - & - \\
IK B & + & - & - & Merah & Kuning & - & - \\
IK C & + & + & + & Merah & Kuning & - & - \\
IK D & + & + & + & Kuning & Kuning & - & + \\
IK E & + & + & - & Kuning & Kuning & - & - \\
IK F & + & + & - & Merah & Merah & - & - \\
IK G & + & + & - & Kuning & Kuning & - & - \\
IK H & + & - & + & Merah & Kuning & - & + \\
\hline
\end{tabular}


Fig.1 Chitinolytic bacteria isolated from Anadara granosa shell

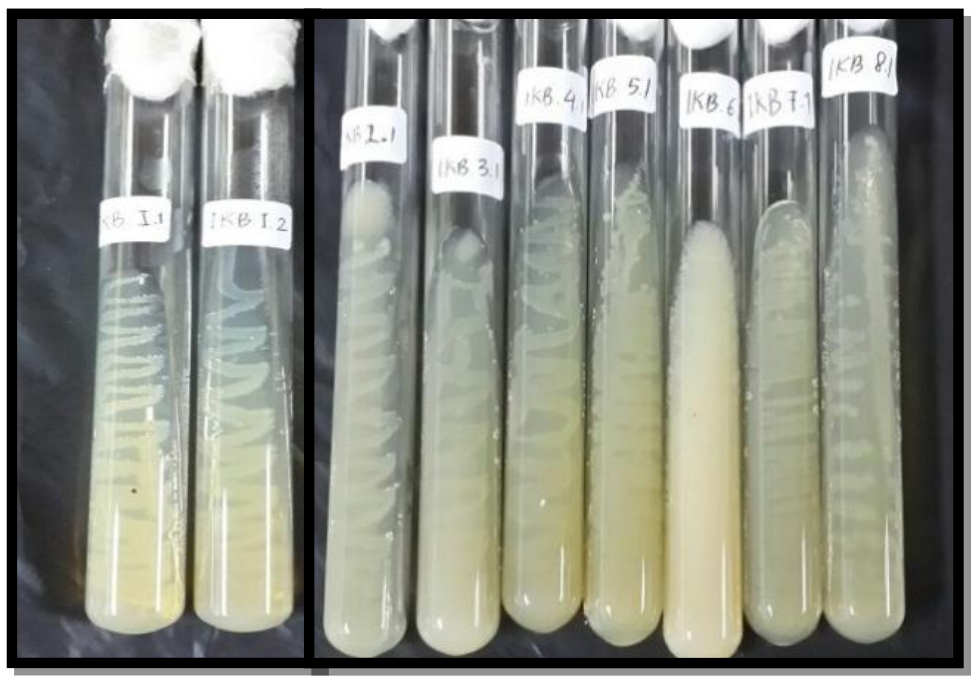

Fig.2 Results rejuvenation fungus Rhizoctonia solani isolates (a) and results rejuvenation isolates of Fusarium sp (b)

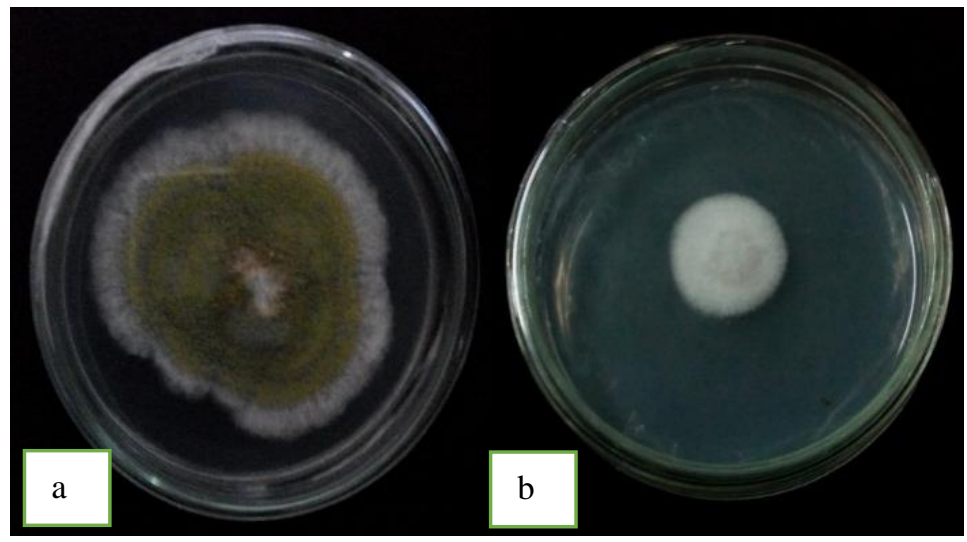

Fig.3 Results inhibition of chitinolytic bacteria against Rhizoctonia solani

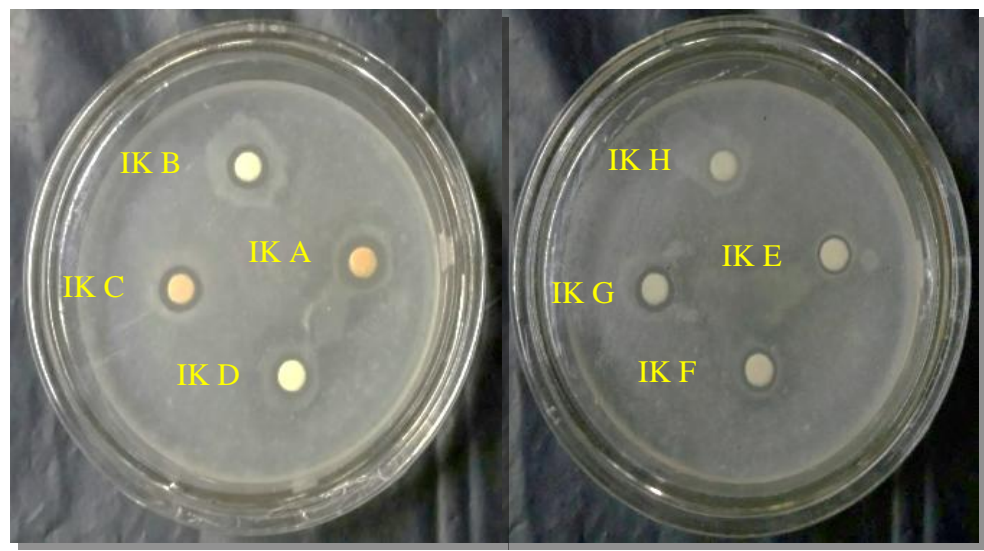


Fig.4 Results of inhibition of chitinolytic bacteria against Fusarium sp

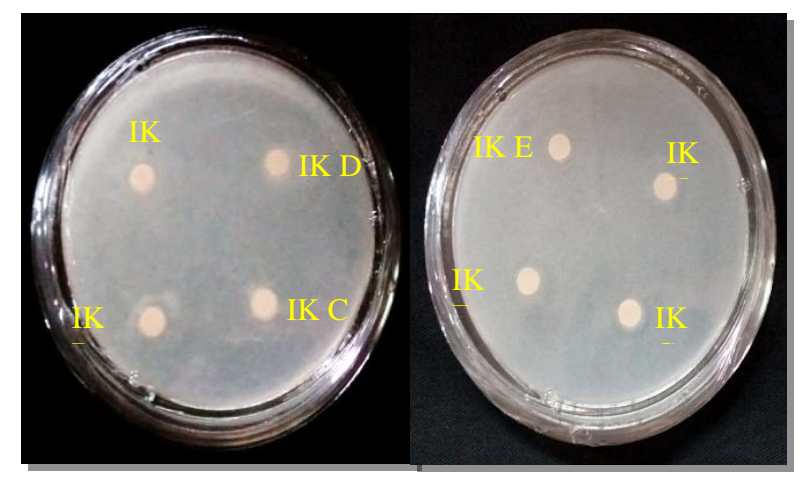

According Fadlya (2008) when the red slant section and yellow butt section then bacteria to ferment glucose, if the slant and butt section colored yellow bacteria to ferment sucrose, glucose and lactose, if the slant section colored yellow and red butt section then bacteria were able to ferment lactose and sucrose, if the slant and butt is red then bacteria are not able to ferment three types of sugar. Gas formation in IK D and IK $\mathrm{H}$ isolates show positive result, seen with the lifting of medium used. Isolates that produce gas is result of fermentation of $\mathrm{H}_{2}$ and $\mathrm{CO}_{2}$. Results for the formation of $\mathrm{H}_{2} \mathrm{~S}$ eighth isolates did not show positive results.

Based on the test results of macroscopic, microscopic (Gram Staining) and biochemical tests chitinolytic bacteria isolated from Anadara granosa shells unidentified species, but according Suryanto and Munir (2006) chitinolytic bacteria can be applied in agriculture as in research which has selected 60 chitinolytic microbial isolates conducted since 1995 in Biotechnology Research Institute for Food Crops, resulting three bacterial isolates producing chitinase featured effective control of soybean rust fungal pathogens. According to Suryanto and Munir (2006) chitinolytic bacterial including Bacillus, Pseudomonas, Vibrios, and Clostridia, and Serratia marcescens has been widely used to control fungal pathogens such as Sclerotium rolfsii, and Aeromonas caviae (Howell and Stipanovic, 1979; Giyanto et al., 2009).

In conclusion, this study has revealed that chitinolytic bacteria isolated from Anadara granosa shells obtained eight isolates ie IK-A, IK-B, IK-C, IK-D, IK-E, IK-F, G and IK-H. Chitinolytic bacteria inhibitory against fungus Rhizoctonia solani showed different results, isolates that have greatest inhibition is A isolates with $1.21 \mathrm{~cm}$ while for smallest inhibition is $\mathrm{H}$ isolates with $0.70 \mathrm{~cm}$ at $1 \times 24$ hour incubation. While the Fusarium $s p$ of eight isolates obtained none of which showed positive results.

\section{References}

Aunstrup, K.O., O. Andressen, E.A. Falch, and T.K. Nielsen. 1979. Production of microbial enzymes. In. Pepples, H.J and D. Perlman (Eds.). Microbial Technol., Academic Press Inc., New York.

Fadlya. 2008. Biochemistry TSI Test. Jakarta. Giyanto, A. A. Nawangsih dan K. H. Mutaqin. 1999. Analisis keragaman molekuler Pseudomonas kelompok fluorescens dengan teknik RAPD (Random Amplified Polymorphic DNA) dan studi potensi antagonistic terhadap Ralstonia solanacearum pada tomat. Laporan Penelitian Proyek Pengkajian dan Penelitian Ilmu 
Pengetahuan Dasar. Dirjen Pendidikan Tinggi. Departemen Pendidikan Nasional.

Gohel, V., A.M. Singh. P., Vimal, Ashwini dan, H.S. Chatpar. 2006. Bioprospecting and Antifungal Potential of Chitinolytic Microorganisms. Afr. J. Biotechnol., 5(2): 54-72.

Howell, C. R. and R. D. Stipanovic. 1979. Control of Rhizoctonia solani in cotton seedling with Pseudomonas fluorescens with an antibiotic produced by the bacterium. Phytopatology 69:480-482.

Irwani, D.K.K. 2012. Distribution and Class Size Length BloodShell (Anadara granosa) in the Coastal Water GenukSubdistrict, Semarang. J. Marine Res., 1(1): 137-145.

Joklik, W., F. dan D., T., Smith. 1968. Microbiology. $15^{\text {th }}$ ed. Prentice-Hall, Inc., New York.

Khaeruni, A., and A. Rahman. 2012. The Use of ChitinolyticBacteria as Biocontrol Agents Stem Rot Disease by Rhizoctonia solani on Soybean Plant. J. Phytopathol. Indonesia, 8(2): 37-43. Jurnal Fitopatologi Indonesia.
Khaeruni, A., Asriantiand Abdul, R. 2012. Effectiveness of Liquid Waste Agriculture as Media Propagation and Formulations Bacillus subtilisas Biological Agents Plant Pathogen. Agroteknos J., 3(3): 144-151.

Pal, K., dan, B., McSpadden Gardener. 2006. Biological Control of Plant Pathogens. The Plant Health Instructor.

Pleban, S., L. Chermin and I. Chet. 1997. Chitinolytic Activity of an Endophytic Stain of Bacillus cereus. Lett. Appl. Microbial., 25: 284-288.

Schoffelmeer, E.A.M., Klis, F.M., Sietsma, J.H. and Cornelissen, B.J.C. 1999. The Cell Wall of Fusarium oxysporum. Fungal Genet. Biol., 27: 275-282.

Suryanto, D., Munir, E. 2006. Utilization Potential Chitinolytic Bacterial Isolates Local for Biological Control Fungus. Proceeding of Research Results Pros., pp.15-25.

Yurnaliza, Sebastian M. and Langkah, S. 2011. The ability of Streptomyces chitinase RKt5 for Antifungal against Pathogen Fusarium oxysporum. J. Nature Indonesia, 14(1).

\section{How to cite this article:}

Nur Haedar, As'adi Abdullah and Besse Fitriani. 2017. Potential of Chitinolytic Bacteria Derived from Anadara granosa Shell to Inhibit Fusarium sp and Rhizoctonia solani Growth. Int.J.Curr.Microbiol.App.Sci. 6(4): 1561-1568. doi: https://doi.org/10.20546/ijcmas.2017.604.192 